\title{
A LEI DE ACESSO À INFORMAÇÃO - LAI E A CONSOLIDAÇÃO INSTITUCIONAL DO MINISTÉRIO PÚBLICO NO BRASIL
}

\author{
Edna Gusmão de Góes Brennand ${ }^{1}$ \\ Universidade Federal da Paraíba
}

\author{
Alexsander de Carvalho Silva ${ }^{2}$
}

Universidade Federal da Paraíba

\section{Resumo}

Examina a relevância da Lei de Acesso à Informação - LAI na consolidação institucional do Ministério Público Federal - MP no Brasil. Analisa a sua a atuação durante o regime militar e no processo de redemocratização após a Constituição de 1988. Aponta a sua evolução como instituição permanente e essencial à função jurisdicional do Estado, responsável, perante o Judiciário, pela defesa da ordem jurídica e dos interesses indisponíveis da sociedade, assim como seu papel na investigação de fatos nacionais sobre os perpetradores de violações aos direitos humanos.

Palavras-chave: Lei de Acesso à Informação. Ministério Público. Violações de direitos humanos.

\section{THE LAW OF ACCESS TO INFORMATION - LAI AND THE INSTITUTIONAL CONSOLIDATION OF THE PUBLIC MINISTRY IN BRAZIL}

\begin{abstract}
It examines the relevance of the Law on Access to Information - LAI in the institutional consolidation of the Federal Public Ministry - MP in Brazil. It analyzes its performance during the military regime and in the process of redemocratization after the 1988 Constitution. It points out its evolution as a permanent and essential institution to the jurisdictional function of the State, responsible, before the Judiciary, for the defense of the legal order and unavailable interests of society and its role in investigating national facts about the perpetrators of human rights violations.
\end{abstract}

Keywords: Access to Information Law. Public ministry. Human rights violations.

\footnotetext{
1 Professora Titular da Universidade Federal da Paraíba. Com Pós-Doutorado na Bélgica (2005); Portugal (2012); Estágio Sênior em andamento na Espanha. Doutorado em Sociologia - Université Paris I Panthéon Sorbonne. Coordenadora da Rede Interdisciplinar em Estudos sobre Violências - RIEV numa parceria com a Universidade Federal de Santa Catarina - UFSC e a Universidade de Valência -Espanha. Desenvolve investigações nos seguintes campos: Democracia e violências, cibercrimes, agir comunicativo, ecossistemas cognitivos, redes digitais e sistemas inteligentes.

${ }^{2}$ Possui formação em Comunicação Social e atua como assessor de imprensa do Ministério Público do Estado da Paraíba. Cursa o Mestrado Profissional em Gestão nas Organizações Aprendentes - MPGOA, da Universidade Federal da Paraíba - UFPB. É integrante da Rede Interdisciplinar de Estudos da Violência - RIEV, sendo pesquisador no projeto "Violações aos Direitos Humanos nas Narrativas de Acervos Audiovisuais Cinematográficos e Sites Abertos". Realiza pesquisa sobre as ações penais do Ministério Público Federal contra os perpetradores de violações dos direitos humanos.
}

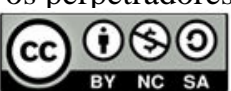

Esta obra está licenciada sob uma Licença Creative Commons Atribuição 4.0 Internacional (CC BY-NC-AS 4.0) LOGEION: Filosofia da informação, Rio de Janeiro, v. 5 n. 2, p.22-37, mar./ago. 2019 


\section{INTRODUÇÃO}

Desde a Declaração Universal dos Direitos Humanos promulgada em 1948, que o acesso à informação pública passa a ser reconhecido como direito humano básico. Esta afirmação está contida no artigo 19: "Todo ser humano tem direito à liberdade de opinião e expressão; este direito inclui a liberdade de, sem interferência, ter opiniões e de procurar, receber e transmitir informações e idéias por quaisquer meios e independentemente de fronteiras"

Entretanto, este direito é efetivado de forma diferenciada em função de questões culturais e identitárias de cada sociedade. É inegável que reconhecer esse direito é de fundamental importância para a democracia e que a garantia do acesso à informação pública é relevante para aumentar a transparência de informações entre cidadãos e seus representantes eleitos, minimizando a crise de representação que têm vivenciado as democracias contemporâneas. Não é possível pensar na autonomia dos cidadãos sem se referir à liberdade de expressão, ao acesso à educação, à informação e à oportunidade social.

A regulamentação da garantia de efetivação do direito de acesso à informação no Brasil é recente embora, assegurada, desde a Constituição Brasileira de 1988 em seu artigo 5o, parágrafo XIV: “é assegurado a todos o acesso à informação e resguardado o sigilo da fonte, quando necessário ao exercício profissional" (BRASIL,1988). Esse marco foi fundamental para o processo de redemocratização brasileira após 21 (vinte e um) anos do regime autoritário, onde as garantias individuais sucumbiram ao lema da Lei de Segurança Nacional. Durante mais de uma década não houve regulamentação legal, ficando o direito de acesso à informação apenas no reconhecimento. É importante salientar que o direito à informação sobre os assuntos do Estado é fundamental para garantir a participação dos cidadãos na fiscalização da execução de suas políticas. A Lei 12.527 de 11 de novembro de 2011 que trata da obrigatoriedade do Estado em fornecer aos cidadãos informações sobre gastos de recursos públicos foi regulamentada através do Decreto Presidencial 7724 de 16 de maio de 2012 (BRASIL, 2012). Esse Decreto inclui a obrigatoriedade de os três Poderes da União, Tribunais de Contas, Ministério Público e entidades privadas sem fins lucrativos darem publicidade a informações referentes à destinação dos recursos públicos por elas recebidos. Foi um avanço considerável que abriu informações de arquivos institucionais dos mais diversos para acesso dos cidadãos brasileiros.

A Lei de Acesso a Informação - LAI foi regulamentada juntamente com a instalação da Comissão Nacional da Verdade (CNV) instituída pelo governo brasileiro após ser condenado pela Corte Interamericana de Direitos Humanos (CIDH). Entre as determinações da Corte Interamericana estava a que obriga o Estado a conduzir, perante a jurisdição ordinária, a 
investigação penal dos fatos da Guerrilha do Araguaia a fim de esclarecê-los, determinar as correspondentes responsabilidades penais e aplicar efetivamente as sanções e consequências que a lei preveja.

Desde 2005 a Organização das Nações Unidas (ONU) tinha recomendado ao governo brasileiro a adoção de medidas para apurar as graves violações aos direitos humanos, denunciadas após o fim da ditadura militar. Nessa recomendação, considerou insuficiente o esforço governamental para pagamento de indenização às vítimas e aos familiares registrados como forma de reconhecimento destes crimes. A ONU solicitou medidas suplementares, como a abertura dos arquivos para amplo conhecimento da sociedade de todas as violações praticadas. Recomendou ainda que fosse amplamente garantido o direito à verdade e transparência para garantia da justiça, uma vez que a lei n.o 6683/79, que concedeu anistia "ampla, geral e irrestrita", alcançou tanto as vítimas como seus algozes.

Essas recomendações tiveram grande impacto no contexto brasileiro, uma vez que estava em curso o processo de consolidação da formação de grupos tais como o Movimento Nacional pelos Direitos Humanos $(\mathrm{MDH})$, posteriormente ao processo de transição democrática. A história do protagonismo do MDH pode ser buscada ao longo de toda a história da evolução social no Brasil. Em função da ocorrência de graves violações durante o regime militar, desde a década de 80, o MDH vem desenvolvendo ações estratégicas por meio de redes nacionais e estaduais.

Não é possível falar em consolidação democrática sem refletir que os direitos humanos possuem ligação direta com a efetivação de processos institucionais e participação democrática, integrando forças sociais e políticas que podem contribuir para o aperfeiçoamento de nossa democracia. Assim, elucidar situações em que ocorram violações de igualdade, exercício de direitos políticos, presunção de inocência, liberdade de pensamento, de opinião, de reunião e de associação tornam-se fundamentais numa sociedade democrática.

Por meio do ato presidencial de 13 de janeiro de 2010, foi instituído o grupo de trabalho com a finalidade de elaborar o anteprojeto de lei para a criação da Comissão Nacional da Verdade - CNV. Esse Projeto, produzido por esse grupo, foi posteriormente encaminhado ao Congresso Nacional em maio de 2010, tendo sido tramitado sob regime de urgência. Disto resulta a promulgação da Lei 12.527/2011, em 16 de maio de 2012, criando a CNV com a finalidade apurar graves violações de Direitos Humanos ocorridas entre 18 de setembro de 1946 e 05 de outubro de 1988. A CNV trabalhou em cooperação com comissões da verdade estaduais, municipais, universitárias, sindicais e de seccionais da Ordem dos Advogados do Brasil (OAB). 
São centenas de grupos formados possibilitando uma mobilização sem precedentes em torno dos temas relacionados à memória, à verdade e à justiça no período do regime militar.

Diversos espaços de reflexão, estão convergindo esforços para percorrer os multifacetados labirintos da memória da ditadura para trazer ao escrutínio da ciência cenas esquecidas, silenciadas, desconhecidas ou renegadas na tentativa de estudar detalhes que poderão servir para a construção de uma democracia cujo mister seja fortalecer espaços públicos de formação da cidadania e para a guarda dos direitos humanos.

Nesse contexto, o acesso à informação é um dos pilares fundamentais. Recentemente um novo quadro se delineia com relação à questão. O Decreto n ${ }^{\circ} 9.690$ de Janeiro de 2019 (BRASIL, 2019) alterou o regulamento da Lei de Acesso à Informação (LAI). Através deste novo mecanismo legal o governo ampliou o número de agentes públicos que podem fazer a classificação dos documentos entre secretos e ultrassecretos. Entra em cena ocupantes de cargos comissionados de segundo e terceiro escalão. Um retrocesso em termos de abertura já que conforme a LAI, seria prerrogativa somente do presidente e vice-presidente da República, ministros de Estado, comandantes das três forças e chefes de missões diplomáticas e consulares no exterior classificar uma informação como ultrassecreta. A Câmera Federal em 19/02/2019 derrubou o referido Decreto que será encaminhado para apreciação no Senado Federal. Apesar disso um grande acervo de documentos já foram acessados e conhecidos por cidadãos e pesquisadores, garantindo assim, o direito de acesso à informação previsto pela LAI.

Nesse cenário de garantia do direito à informação justifica-se a criação da Rede Interdisciplinar de estudos sobre Violências - RIEV (www.ufpb.br/riev). A rede é formada por pesquisadores de Programas de Pós-graduação da Universidade Federal da Paraíba-UFPB, Universidade Federal de Santa Catarina - UFSC e a Universidade de Valência na Espanha. Desde 2017 os grupos de pesquisa vêm desenvolvendo investigações interdisciplinares sobre formas de violência, com ênfase analítica nos perpetradores de violações de direitos humanos no Brasil.

Em função da especificidade do amplo acervo colocado à disposição da sociedade brasileira com a Lei de Acesso à Informação (LAI) e a instalação da Comissão Nacional da Verdade (CNV), desnuda-se um terreno fértil e idôneo para investigar as representações e fatos nacionais sobre os perpetradores de violações aos direitos humanos. Os resultados contidos nos três Relatórios da Comissão da Verdade abrem um amplo leque de possibilidades de leituras. As pesquisas desenvolvidas na RIEV investigam os seguintes acervos: filmes e documentários, sites abertos, documentos e relatórios diversos sobre o regime militar no Arquivo Nacional, nas Comissões estaduais e municipais e nos acervos de universidade. 
A ênfase é dada em quem os praticou e como foram registrados. Ressignificar a memória sobre essas graves violações possibilitará aprofundar estudos sobre esse período conturbado. Partimos do pressuposto de que o silêncio, sobre quem foram os atores concretos das ações repressivas que resultaram em graves violações aos direitos humanos, precisa ser quebrado. $\mathrm{O}$ silêncio sobre os responsáveis por esses danos e suas repercussões podem abrir diversas portas para investigações relevantes.

Assim, neste artigo foram particularizados aspectos da pesquisa realizada no âmbito da RIEV relacionados à atuação do Ministério Público no que se refere à responsabilização penal dos violadores dos direitos humanos. O foco é analisar a consolidação institucional do Ministério Público como órgão essencial não só ao sistema de justiça do Brasil bem como à sociedade brasileira.

\section{A EVOLUÇÃO DO PAPEL DO MINISTÉRIO PÚBLICO: ENTRE CONTROLAR E DEMOCRATIZAZAR INFORMAÇÕES PÚBLICAS}

O Ministério Público é uma das principais instituições do ordenamento jurídico brasileiro. Conforme a Constituição de 1988, cabe ao MP a defesa da ordem jurídica, do regime democrático e dos interesses sociais e individuais indisponíveis. O combate à corrupção, principalmente em operações como a Lava Jato, tornou o órgão ministerial um dos mais difundidos no noticiário nacional.

As atribuições concedidas ao Ministério Público brasileiro pela Constituição de 1988 o tornaram único no mundo. Mazzili (1998, p. 23) afirma que, hoje, o MP já está consagrado com autonomia e independência funcional, não se limitando mais ao papel de persecução criminal e nem tão pouco sustentando os interesses dos governantes. "Passou, pois, a ser órgão de proteção das liberdades públicas constitucionais, de defesa dos direitos indisponíveis, de garantia do contraditório".

Entretanto, as conquistas que resultaram nessa instituição, de reconhecida confiança pela sociedade brasileira, não foram obtidas de modo repentino na Constituição Cidadã; foi sim o resultado de uma consolidação institucional de décadas, que se intensificou especialmente durante o regime militar brasileiro, ocorrido no período de 1964 a 1985. 


\title{
2.1 O MINISTÉRIO PÚBLICO COMO INSTITUIÇÃO DE CONTROLE
}

Com a deposição de João Goulart pelos militares, em 1964, tem-se o início um dos períodos mais problemáticos da história do Brasil. Como ocorre sempre que um regime ditatorial se instala, uma nova constituição foi promulgada em 1967 à imagem e semelhança do governo à época. Essa Constituição manteve basicamente para o Ministério Público as mesmas características da Carta Magna de 1946, entre elas a inclusão do MP no capítulo dedicado ao Poder Judiciário.

Entretanto, o viés autoritário está presente na Constituição ao estabelecer, no artigo 151, a caracterização de abuso de direitos individuais. O artigo dá poder ao Ministério Público, através do Procurador-Geral da República, de representar para retirada de direitos.

\begin{abstract}
Art. 151 - Aquele que abusar dos direitos individuais previstos nos $\S \S 8^{\circ}, 23.27$ e 28 do artigo anterior e dos direitos políticos, para atentar contra a ordem democrática ou praticar a corrupção, incorrerá na suspensão destes últimos direitos pelo prazo de dois a dez anos, declarada pelo Supremo Tribunal Federal, mediante representação do Procurador-Geral da República, sem prejuízo da ação civil ou penal cabível, assegurada ao paciente a mais ampla, defesa. (CONSTITUIÇÃO FEDERAL, 1967).
\end{abstract}

Os direitos estabelecidos pelos parágrafos $8^{\circ}, 23,27$ e 28 do artigo 150 da Constituição são os de manifestação de pensamento, de convicção política ou filosófica e a prestação de informação; exercício de qualquer trabalho, ofício ou profissão; o direito de reunião e a liberdade de associação. Como é o Procurador-Geral da República que tem a atribuição de representar aqueles que abusariam desses direitos, o Ministério Público se torna um braço autoritário do regime.

Paes (2003, p. 176) destaca que até a Constituição de 1967, o Ministério Público tinha como função primeira a defesa dos interesses do Estado e não da sociedade. E são esses interesses estatais que os militares buscam garantir por meio do órgão ministerial.

A instituição se encontrava muito longe de ser defensora dos direitos e interesses da sociedade do povo, dos cidadãos. Primeiro, porque tinha dever constitucional de defender o Estado; segundo, porque a dependência, a subordinação ao Poder Executivo não lhe permitia atuar contra a administração pública, já que o que se buscava era impedir e anular os atos que se revelassem contrários aos interesses públicos (PAES, 2003, p. 176).

Desde o início do governo, os militares buscaram garantir legitimidade através da edição de Atos Institucionais, sendo o mais conhecido deles no Ato Institucional $n^{\circ} 5$, que instaurou de vez a ditadura no país, que deu ao Executivo o poder de fechar o congresso, estabeleceu a censura prévia e suspendeu o habeas corpus.

Em 17 de outubro de 1969, a Junta Militar, que governava o país após a edição do Ato Institucional $n^{\circ} 16$ (que dava ao Executivo o poder de legislar), editou a Emenda Constitucional 
$\mathrm{n}^{\text {o }} 1$, que ao alterar tantos dispositivos da Constituição de 1967, passou a funcionar como uma nova constituição. Neste novo diploma legal, o uso do Ministério Público como legitimação institucional e como forma de controle para a ditadura avançou um pouco mais.

Na Constituição de 1967, o MP estava localizado no Capítulo do Poder Judiciário na Constituição de 1967 (Capítulo VIII, Seção IX). Na emenda de 1969, passa para o Capítulo do Poder Executivo (Capítulo VII, Seção). Mais uma vez o chamado abuso de direito individual ou político está presente na legislação cabendo ao Procurador-Geral da Republica a propositura da representação.

Além disso, o Procurador-Geral da República ganhou outra atribuição que implica no uso no MP para controle: a representação por inconstitucionalidade de lei ou ato normativo federal ou estadual (artigo 119, alínea 1 da Emenda). A representação por inconstitucionalidade já estava prevista desde a Constituição de 1937, mas apenas para fins de intervenção federal nos estados. A nova norma possibilitava que leis e outros atos normativos fossem declarados inconstitucionais pelo Supremo Tribunal Federal a partir de representação do PGR. É preciso destacar que o PGR continuava sendo escolhido pelo presidente da República, podendo ser demitido a qualquer tempo. Além disso, nos processos referentes aos crimes contra a Segurança Nacional, o PGR podia requerer a suspensão do exercício do mandato parlamentar ao STF.

Conforme destaca Arantes (2002, p. 39):

O Ministério Público, como órgão vinculado e dependente do Poder Executivo, desempenhou função estratégica nessa época, graças a uma ampliação significativa de suas atribuições legais e constitucionais. Mais precisamente, os militares fizeram de seu órgão de cúpula - A Procuradoria-Geral da República - um agente importante da tentativa ambígua de institucionalizar a revolução, isto é, de governar não só pela força, mas também por meio da lei.

As atribuições do Procurador-Geral de Justiça foram ampliadas pela Emenda Constitucional $\mathrm{n}^{\circ}$ 7, editada pelo presidente Ernesto Geisel, em 1977, que estabelecia a representação não só por inconstitucionalidade, mas também para interpretação de lei ou ato normativo federal ou estadual. Dessa forma, o PGR se tornou uma espécie de fiscal dos estados para o governo federal. Outro ponto importante dessa emenda foi o dispositivo que estabeleceu o poder de o Supremo Tribunal Federal avocar as causas processadas perante quaisquer juízos ou Tribunais. O pedido de avocação só poderia ser feito pelo Procurador-Geral da República quando houvesse perigo de grave lesão à ordem, à saúde, à segurança ou às finanças públicas. “A avocatória veio arrematar a concentração do sistema de controle judicial das leis e atos normativos no Brasil durante o regime militar" (ARANTES, 2002, p. 42). 


\subsection{A CONSOLIDAÇÃO INSTITUCIONAL E A INTERVENÇÃO EM CAUSAS DE INTERESSE PÚBLICO.}

Se de um lado, a ditadura militar concedeu novas atribuições ao Ministério Público com o objetivo de legitimar o regime, de outro, muitos avanços ocorreram nesse período que vieram consolidar a importância da instituição para a sociedade. A primeira delas é a equiparação salarial entre os membros do Ministério Público e os juízes prevista no artigo 139, parágrafo único da Constituição de 1967.

Um dos passos mais importantes foi a aprovação de um novo Código de Processo Civil em 1973. O artigo 82 da lei estabelecia as atribuições da instituição.

\footnotetext{
Art. 82. Compete ao Ministério Público intervir: I - nas causas em que há interesses de incapazes;

II - nas causas concernentes ao estado da pessoa, pátrio poder, tutela, curatela, interdição, casamento, declaração de ausência e disposições de última vontade;

III - em todas as demais causas em que há interesse público evidenciado pela natureza da lide ou qualidade da parte. (CÓDIGO DE PROCESSO CIVIL, 1973)
}

Arantes (2002) destaca que, historicamente, a atuação do Ministério Público na esfera civil esteve ligada a processos referentes aos direitos individuais indisponíveis (nos quais o órgão atuava como fiscal da lei) e processos envolvendo indivíduos considerados incapazes. Essas duas questões estão presentes nos dois primeiros incisos do Código de 1973.

\footnotetext{
Essas duas funções estão fortemente marcadas pela ideia de uma dupla fragilidade a requerer proteção estatal, respectivamente, a fragilidade do indivíduo incapaz e a fragilidade da sociedade em preservar certos valores e direitos que ela mesma definiu um dia como permanentes e que, exatamente por isso, são fixados como indisponíveis no ordenamento jurídico (ARANTES, 2002, p. 26).
}

Para o Código Civil, eram considerados incapazes os menores de 16 anos, os loucos, os surdos, os ausentes, e, em alguns atos, as pessoas entre 16 e 21 anos, os pródigos e os silvícolas. Neste caso, o Ministério Público ganhou a atribuição de intervir nos processos daqueles que, pela legislação, não tinham condições de representar a si mesmos e poderiam ter seus direitos não garantidos.

Essas atribuições, de certa forma, já estavam previstas em Códigos anteriores. O ponto de inflexão na história do Ministério Público aparece no inciso terceiro do artigo 82 do Código de Processo Civil que estabelece como atribuição do MP a intervenção nas causas de interesse público. Arantes (2002) aponta esse dispositivo como o primeiro passo dado pelo órgão ministerial de deslocamento do Poder Executivo e transposição para o lado da sociedade.

Como o Código de Processo Civil não definiu o que significava "interesse público", o Ministério Público passou a atuar no máximo de casos em defesa do interesse público. Segundo 
Arantes (2002, p. 34), membros do MP passaram a advogar a tese de que o inciso III "não só exigia a sua presença em todas as causas envolvendo interesse público como caberia ao próprio órgão do Ministério Público interpretar a existência ou não desse interesse nos casos concretos". A partir daí a instituição passou a atuar em casos de acidentes de trabalho, desapropriação, entre outros.

O ano de 1981, período de abertura do governo Figueiredo, representou um marco importante para a consolidação institucional do Ministério Público brasileiro. Em 31 de agosto, foi sancionada a Lei $\mathrm{n}^{\circ}$ 6.938, que instituiu a Política Nacional do Meio Ambiente, seus fins e mecanismos de formulação e aplicação. Essa lei, no seu artigo 14, parágrafo $1^{\circ}$, concedeu ao Ministério Público da União e dos Estados a legitimidade para propor ação de responsabilidade civil e criminal, por danos causados ao meio ambiente. Conforme Arantes (2002, p. 51), foi a primeira norma jurídica a formalizar um direito difuso.

De acordo com Zanetti Júnior (2005, p. 3,4), direitos difusos são

[...] aqueles transindividuais (metaindividuais, supraindividuais, pertencentes a vários indivíduos), de natureza indivisível (só podem ser considerados como um todo), e cujos titulares sejam pessoas indeterminadas (ou seja, indeterminabilidade dos sujeitos, não há individuação) ligadas por circunstâncias de fato [...].

Arantes (2002) aponta duas importantes inovações introduzidas pela Lei 6.938. A primeira é a instituição da chamada responsabilidade objetiva pela qual é desnecessário demonstrar a existência de elemento subjetivo da culpa do ato lesivo ao meio ambiente. A segunda é a irrelevância da licitude da atividade causadora do dano. Por este princípio, "o responsável tem de responder pelos danos causados, mesmo que sua atividade conte com a aprovação dos órgãos públicos competentes" (ARANTES, 2002, p. 52).

O mais importante em relação à atuação do Ministério Público é que, conforme Goulart (2003, p. 86), a Lei da Política Nacional do Meio Ambiente que rompeu com os princípios individualistas do Código de Processo Civil e "conferiu ao Ministério Público legitimidade para a propositura de ação civil pública ambiental, reconhecendo-o como canal privilegiado da sociedade para a tutela dos interesses difusos em juízo, alargando o acesso à Justiça".

O outro ponto importante no avanço institucional do Ministério Público ocorrido em 1981 foi a aprovação da Lei Complementar n 40, a Lei Orgânica Nacional do Ministério Público dos Estados. Sua aprovação decorreu da Emenda Constitucional no 7, de 1977, que estabelecia a necessidade de uma lei complementar, de iniciativa do Presidente da República, contendo as normas gerais a serem adotadas na organização do Ministério Público Estadual.

O primeiro ponto relevante da lei é a definição de Ministério Público. $\mathrm{O}$ artigo $1^{\circ}$ define o MP como uma instituição permanente e essencial à função jurisdicional do Estado, 
responsável, perante o Judiciário, pela defesa da ordem jurídica e dos interesses indisponíveis da sociedade, pela fiel observância da Constituição e das leis. Essa lei orgânica foi tão fundamental na organização da instituição que sua definição foi incorporada pela Constituição de 1988. "O que hoje se valoriza no Ministério Público como contribuição para a democracia no Brasil - seu novo perfil institucional - foi-lhe atribuído em grande medida antes do pacto constitucional de 1988" (ARANTES, 2002, p. 46). O que a Constituição de 1988 acrescentou na definição institucional do Ministério Público foi a defesa do regime democrático.

Outro ponto importante foi estabelecer a unidade, a indivisibilidade e a autonomia funcional como princípios institucionais do Ministério Público. Antes os Ministérios Públicos estaduais tinham características distintas.

Neste interim, é importante apontar as diferenças de organização e funcionamento dos Ministérios Públicos nos Estados nesse período. Para tanto, foram selecionados cinco Ministérios Públicos, um de cada região brasileira para análise comparativa entre as Leis Orgânicas de cada um vigentes até a aprovação da Lei Complementar n 40: São Paulo, Paraíba, Santa Catarina, Goiás e Pará.

O MP de São Paulo era o mais avançado institucionalmente do país; isso porque desde a Lei estadual n ${ }^{\circ}$ 2.878/1954, conhecida como Lei Áurea do Ministério Público, o ProcuradorGeral de Justiça era escolhido pelo governador do Estado por meio de uma lista tríplice formada por integrantes da carreira do MP. Na Lei Orgânica do MP de São Paulo, a Lei Estadual $n^{\circ}$ 10.165/1968, foram estabelecidos como representantes da instituição o Procurador Geral da Justiça; o Colégio de Procuradores da Justiça; o Conselho Superior do Ministério Público; o Corregedor Geral do Ministério Público; os Procuradores da Justiça do Estado; os Promotores Públicos e Curadores; e os Promotores Públicos Substitutos.

Já na Paraíba, vigorava a Lei Complementar $n^{\circ}$ 1/1971, primeira Lei Orgânica do MP no Estado. A lei definia a instituição como órgão do poder executivo. O MPPB era composto pelo Procurador-Geral de Justiça (diretamente subordinado ao governador e escolhido por ele dentre os cidadãos graduados em Direito, portanto, fora da carreira do MP), pelos Procuradores de Justiça (que atuavam nas Câmaras do Tribunal de Justiça), pelo Corregedor (nomeado pelo governador entre três Promotores de Justiça indicados), pelos Promotores de Justiça, pelos Advogados de Ofício (atuais Defensores Públicos), pelos Procuradores do Tribunal de Contas. Ou seja, pela lei, a mesma instituição abrigava os responsáveis por acusar e por defender uma pessoa.

O Ministério Público de Santa Catarina, por sua vez, tinha uma organização completamente diferente. A Lei Orgânica local (Lei n 4.557/1971) estabelecia que, além de 
zelar pela execução da lei e os interesses da sociedade, a instituição também representava a defesa judicial dos interesses do Estado, bem como o patrocínio da Fazenda Pública. O chefe do MP era designado pela lei como Procurador-Geral do Estado, não Procurador-Geral de Justiça, como em outros Ministérios Públicos. Eram membros do MP catarinense o Procurador Geral do Estado; os Procuradores do Estado; os Promotores Públicos; e os Promotores Substitutos.

Já o Ministério Público de Goiás tinha uma organização mais parecida com a de São Paulo. A Lei 7.760/1973 definia como órgãos da instituição a Procuradoria Geral de Justiça; o Colégio de Procuradores da Justiça; o Conselho Superior do Ministério Público; e a Corregedoria-Geral do Ministério Público. Eram considerados membros do MP o Procurador Geral de Justiça, os Procuradores da Justiça e os Promotores de Justiça.

O Ministério Público do Pará também tinha uma organização diferenciada. A Lei 3.346/1965 definia como órgãos da instituição o Procurador Geral do Estado; o Sub-Procurador Geral do Estado; o Corregedor do Ministério Público; o Secretário do Ministério Público; os Promotores Públicos; os Adjuntos de Promotor Público; os Curadores Gerais de Órfãos, Interditos e Ausentes, Massas Falidas, Resíduos e Fundações; os Curadores Promotores de Menores sob o amparo do Código de Menores; os Curadores de Acidentes do Trabalho; os Advogados da Assistência Judiciária Cível; os Advogados de Ofício que funcionam nos Juízos Penais. O Procurador-Geral, o subprocurador e os adjuntos de Promotor eram cargos de livre nomeação e demissão pelo governador do Estado; os demais eram cargos de carreira com ingresso por concurso.

A Lei Orgânica Nacional do MP veio exatamente trazer unidade institucional em todo o país. $\mathrm{O}$ artigo $4^{\circ}$ estabelecia que a instituição seria organizada em carreira e teria autonomia administrativa e financeira, com dotação orçamentária. Já o artigo $5^{\circ}$ estabelecia os órgãos integrantes da instituição.

“Art. 5 - O Ministério Público dos Estados será integrado pelos seguintes órgãos:

a) Procuradoria-Geral de Justiça;

b) Colégio de Procuradores;

c) Conselho Superior do Ministério Público;

d) Corregedoria-Geral do Ministério Público;

II - de execução:

a) no segundo grau de jurisdição: o Procurador-Geral de Justiça e os Procuradores de Justiça;

b) no primeiro grau de jurisdição: os Promotores de Justiça. (LEI COMPLEMENTAR No 40/1982)".

Com isso, o Ministério Público foi uniformizado em todo o país, não podendo mais abranger os advogados de ofício, os procuradores do Tribunal de Contas, os adjuntos e outros cargos que eram de livre nomeação e demissão pelo chefe do Poder Executivo. A instituição 
será formada por integrantes de carreira e seus órgãos administrativos serão os mesmos e terão as mesmas atribuições em todos os estados.

Outro ponto importante dessa norma foi estabelecido no artigo 55 que determinava que pessoas estranhas à instituição não poderiam exercer funções nela. Isto vedou a escolha do chefe do MP, o Procurador-Geral de Justiça, entre pessoas fora da carreira ministerial, como ocorria em vários estados, a exemplo da Paraíba.

Essas mudanças já se refletem nas leis orgânicas estaduais que foram aprovadas nos anos seguintes. Em Santa Catarina, foi aprovada a Lei Complementar $n^{\circ} 17$, de 5 de julho de 1982, a nova Lei Orgânica do MP local. O Procurador-Geral deixa de ser do Estado e passa a ser de Justiça, que passa a ser nomeado pelo governador do Estado dentre os membros da Instituição com mais de dez anos de carreira (artigo $7^{\circ}$ ). Além disso, desaparecem da carreira do MPSC os procuradores do Justiça, permanecendo os promotores e procuradores de Justiça.

No Ministério Público da Paraíba, a Lei Complementar nº 28, de 1982, retira da carreira ministerial os advogados de ofício e os procuradores do Tribunal de Contas, ficando os promotores de Justiça, com atuação na primeira instância judicial, e os procuradores de Justiça, que atuavam na segunda instância.

No Pará, o Ministério Público também ganhou uma nova Lei Orgânica, em 1982, a Lei Complementar $n^{\circ} 1$. Por esta nova norma, todos os cargos em comissão que eram de livre nomeação do governador, como o subprocurador e os adjuntos de promotor, foram retirados; a instituição passa a abrigar apenas os cargos de carreira, com entrada via concurso público. $\mathrm{O}$ avanço foi maior ainda em relação à escolha do chefe da instituição. Se a primeira lei estabelecia que livre o Procurador-Geral era de livre nomeação e demissão do Chefe do Poder Executivo, recaindo a escolha entre os Doutores em Direito ou Bacharéis em Ciências Jurídicas e Sociais; a nova lei o PGJ passa a ser "nomeado pelo Governador do Estado, dentre uma lista tríplice, integrada por Procuradores de Justiça, para um mandato de dois (2) anos, prorrogável uma vez”. Neste aspecto, o MP do Pará segue o modelo do MP de São Paulo.

Os Ministérios Públicos de Goiás e de São Paulo mantiveram suas composições com as novas leis aprovadas, respectivamente, a Lei 9991/1986 e a Lei Complementar 304/1982. A principal mudança no MP de Goiás ocorre na nomeação do Procurador-Geral de Justiça. Apesar de continuar sendo feita diretamente pelo governador, ela se dá entre os integrantes da carreira ministerial com mais de 10 anos e não mais entre os cidadãos.

\footnotetext{
A lei de 1981, em particular, foi muito importante nesse sentido, pois estabeleceu as bases do processo de independência e fortalecimento nacionais do Ministério Público que culminaria com a Constituição de 1988, especialmente ao fixar o principio tutelar da relação entre a instituição e os interesses indisponíveis da sociedade (ARANTES, 2002, p. 48).
} 
Todas essas conquistas obtidas durante sua história e, principalmente, durante a conturbada ditadura militar preparam a instituição para o salto que ocorreria com a Constituição de 1988, em especial, quando à independência institucional. Os avanços não foram alcançados por mero acaso; são frutos da luta institucional. Se por um lado, como mostrado, a ditadura militar deu poderes à instituição como forma de manter o controle sobre o país, por outro, as conquistas de atribuições, principalmente no que diz respeito à defesa dos direitos sociais e coletivos, foram obtidas com luta, convencimento e muito lobby da classe.

Os membros do Ministério Público foram adquirindo, ao longo das décadas de 1950, 1960 e 1970, consciência corporativa. Eles conpreenderam que, para obterem a instituição que desejavam, deveriam participar da luta política pela reforma das leis. Toda essa evolução institucional ao longo do século XX vai redundar na Constituição de 1988 e no novo perfil institucional conquistado pelo Ministério Público.

\section{CONSIDERAÇÕES FINAIS}

Foi possível verificar ao longo da pesquisa que as relações entre o Ministério Público e a ditadura militar tiveram uma dupla forma: de um lado, o governo dos militares utilizou a instituição, principalmente o chefe do Ministério Público da União - o Procurador-Geral da República - para conferir legitimidade ao regime e para exercer controle sobre a sociedade por meio das leis. Isso ocorreu tanto no sentido macro por meio do controle de constitucionalidade das leis, quanto no sentido micro e individual por meio da representação por abuso de direitos. Por outro lado, foi nesse período que a instituição mais se fortaleceu, ganhando novas atribuições, pavimentando, dessa forma, o caminho que iria resultar nas conquistas do período democrático com a Constituição. Os dados confirmam que no período do regime militar o MP avançou em sua institucionalidade através da aquisição de novas atribuições pelo Código de Processo Civil de 1973 quanto na Lei da Política Nacional do Meio Ambiente. Esse avanço ocorreu ainda pela estruturação e uniformização dos Ministérios Públicos dos Estados que, conforme demonstrado através dos exemplos das cinco regiões, passaram do formato regional - alguns dos quais díspares em relação aos outros - a um formato nacional seguido por todos os órgãos nos estados.

A Constituição de 1988 tornou o Ministério Público uma instituição essencial à Justiça não subordinada a nenhum dos três poderes da República, defensor dos interesses sociais, não mais de governantes; defensor da democracia, não mais podendo ser utilizado por nenhum tipo 
de ditadura. Trata-se do ápice de uma história institucional que começou no Brasil Colônia, prosseguiu no Império na República, se intensificando ironicamente na ditadura militar.

A LAI está permitindo o acessar e estudo de documentos produzidos pelo Ministério Público, o que está possibilitando um olhar analítico sobre os perpetradores porque eles são o foco e alvo principal das ações penais do Ministério Público Federal. O MP, como braço do Estado brasileiro responsável pela persecução penal dos crimes, atua para punir os responsáveis pelas violações dos direitos humanos que se configuram crime pela lei brasileira. Neste contexto, o Relatório Crimes da Ditadura Militar (2017) do Grupo de Trabalho Justiça de Transição (GTJT) do Ministério Público Federal revela detalhes de 27 ações penais ajuizadas entre 2012 e 2016 contra 47 agentes envolvidos em 43 crimes (11 homicídios, 9 falsidades ideológicas, 7 sequestros, 6 ocultações de cadáver, 2 quadrilhas armadas, 2 fraudes processuais, 1 estupro, 1 favorecimento pessoal, 1 transporte de explosivos, 1 lesão corporal e 2 abusos de autoridade) cometidos contra 37 vítimas.

$\mathrm{Na}$ atualidade, o Ministério Público não é mais o braço do Poder Executivo para legitimar suas ações e perseguir seus inimigos; ele é o braço da sociedade responsável pela defesa dos direitos dos cidadãos. Isso significa que o MP exerce, nos dias atuais, um mister efetivamente público, fruto de um processo de conquistas que se confunde com a história do Brasil. 


\section{REFERENCIAS}

ARANTES, Rogério Bastos. Ministério Público e Política no Brasil. São Paulo: Editora Sumaré, 2002.

BRASIL. Constituição Federal de 1988. Disponível em http://www.planalto.gov.br/ccivil_03/Constituicao/Constituicao.htm Acesso em 10 jan. 2019.

Constituição Federal de 1967. Disponível em http://www.planalto.gov.br/ccivil_03/Constituicao/Constituicao67.htm Acesso em 9 jan. 2019.1

Emenda Constitucional No 1, de 17 de outubro de 1969. Disponível em http://www.planalto.gov.br/ccivil_03/Constituicao/Emendas/Emc_anterior1988/emc01-69.htm Acesso em 9 jan. 2019.

Código de Processo Civil. Lei no 5.869, de 11 de janeiro de 1973. Disponível em http://www.planalto.gov.br/ccivil_03/leis/L5869impressao.htm Acesso em 10 jan. 2019.

Lei Complementar $\mathbf{N}^{\mathbf{0}}$ 40, de 14 de dezembro de 1981. Disponível em: http://www.planalto.gov.br/ccivil_03/leis/lcp/Lcp40.htm Acesso em 11 jan. 2019.

Lei $\mathbf{n}^{\mathbf{0}}$ 6.938, de 31 de agosto de 1981. Disponível em:

http://www.planalto.gov.br/ccivil_03/leis/L6938.htm Acesso em 11 jan. 2019.

GOIÁS. Lei no 7.760, de 20 de novembro de 1973. Disponível em:

http://www.gabinetecivil.go.gov.br/leis_ordinarias/1973/lei_7760.htm Acesso em 11 jan. 2019.

Lei no 9.991, de 31 de janeiro de 1986. Disponível em:

http://www.gabinetecivil.goias.gov.br/leis_ordinarias/1986/lei_09991.htm Acesso em 11 jan. 2019.

Congresso Nacional. Lei No 12.527, de 18 de Novembro de 2011. Disponível em: <http://www.planalto.gov.br/ccivil_03/_Ato2011-2014/2011/Lei/L12527.htm >. Acesso em 30 jun. 2017. 2012 :

Lei de Acesso à Informação LAI - Decreto no. 7.724, de 16 de maio de 2012. Brasília, DF,

Decreto nº 9.690 de Janeiro de 2019. Disponível em

http://www.in.gov.br/materia//asset_publisher/Kujrw0TZC2Mb/content/id/60344275. Acesso em fev. 2019.

GOULART, Marcelo Pedroso. Ministério Público e democracia: teoria e práxis. Leme: Editora do Direito, 1998.

MAZZILLI, Hugo Nigro. Introdução ao Ministério Público. São Paulo: Saraiva, 1998.

PAES, José Eduardo Sabo. O Ministério Público na construção do Estado Democrático de Direito. Brasília: Brasília Jurídica, 2003.

PARÁ. Lei no 3346, de 17 de setembro de 1965. Disponível em: http://bancodeleis.alepa.pa.gov.br:8080/arquivos/lei3346_1965_11317.pdf Acesso em 11 jan. 2019. 
Lei Complementar $\mathbf{n}^{\circ}$ 01, de 10 de novembro de 1982. Disponível em https://www2.mp.pa.gov.br/sistemas/gcsubsites/upload/40/legislacao_estadual_lei-001.pdf Acesso em 10 jan. 2019.

PARAÍBA. Lei Complementar no 01, de 17 de fevereiro de 1971. Disponível em: http://sapl.al.pb.leg.br/sapl/consultas/norma_juridica/norma_juridica_mostrar_proc?cod_norma=7 Acesso em 11 jan. 2019.

Lei Complementar no 28, de 06 de julho de 1982. Diário Oficial do Estado, 1982.

SANTA CATARINA. Lei $\mathbf{n}^{\mathbf{0}} \mathbf{4 5 5 7}$, de 4 de janeiro 1971. Disponível em: http://leisestaduais.com.br/sc/lei-ordinaria-n-4557-1971-santa-catarina-dispoe-sobre-a-lei-organica-doministerio-publico-na-forma-do-art-99-da-constituicao-estadual-vigente-cria-e-extingue-cargos-e-daoutras-providencias-1971-06-25-versao-consolidada Acesso em 12 jan. 2019.

Lei Complementar no 17, de 5 de julho de 1982. Disponível em:

http://leisestaduais.com.br/sc/lei-complementar-n-17-1982-santa-catarina-dispoe-sobre-a-lei-organicado-ministerio-publico-do-estado-de-santa-catarina Acesso em: 12 jan. 2019.

SÃO PAULO. Lei n. 10.165, de 28 de junho de 1968. Disponível em: https://www.al.sp.gov.br/repositorio/legislacao/lei/1968/lei-10165-28.06.1968.html. Acesso em 12 jan. 2019.

Lei Complementar no 304, de 28 de dezembro de 1982. Disponível em: https://www.al.sp.gov.br/repositorio/legislacao/lei.complementar/1982/lei.complementar-30428.12.1982.html Acesso em 12 jan. 2019.

ZANETI JÚNIOR, Direitos coletivos lato sensu: a definição conceitual dos direitos difusos, dos direitos coletivos stricto sensu e dos direitos individuais homogêneos. In AMARAL, Guilherme Rizzo; CARPENA, Márcio Louzada (coords.). Visões críticas do processo civil brasileiro: uma homenagem ao Prof. Dr. José Maria Rosa Tesheiner. Porto Alegre: Livraria do Advogado, 2005. 